\title{
Municipalities without elected councils. Causes of insufficient fulfilment of candidate lists in some municipalities in local elections in $2018^{1}$
}

\author{
PETR DVOŘÁK AND STANISLAV BALÍK
}

\section{sciendo}

Politics in Central Europe (ISSN: 1801-3422)

Vol. 17, No. 1

DOI: 10.2478/pce-2021-0003

\begin{abstract}
By means of a qualitative analysis of the sixteen municipalities in the Czech Republic in which additional elections were held in 2019, five variables were identified which may explain why additional elections occurred. For analysis, we used data from the Czech Statistical Office (municipal elections 1994 to 2019), the Ministry of Interior of the Czech Republic and information on individual municipalities from media analysis. We have identified the following possible variables which may affect whether additional elections are held: end of elites, non-stand as a candidate again, the end of municipal representatives, incumbent decides not to defend mandate (variable Non-defend mandate) and personal disputes within the municipality. Conversely, the financial situation of the municipality, the age of the representatives, the voter turnout in the municipality, the number of voters, the number of candidate lists or associations and candidates proved inconclusive in most municipalities. A significant increase in new candidates is a consequence rather than an explanation of the holding of additional elections.
\end{abstract}

Key words: local elections, additional elections, The Czech Republic, quality research, candidates

1 This publication was written at Masaryk University with the support of the Specific University Research Grant provided by the Ministry of Education, Youth and Sports of the Czech Republic. The authors would like to thank anonymous referees for their useful comments and Jan Černý for help with media analysis. 


\section{Introduction}

Recently, local policy research about the Czech Republic has enjoyed considerable interest, whether it is the debate over the direct election of mayors (Jüptner 2012), the preferential votes of voters (Šedo 2009), the causes of early elections (Jaroš - Balík 2018), verification of the argument of efficiency from the economic point of view in the smallest municipalities in the Vysočina region (Burešová - Balík 2019), coalitions at the municipal level (Jüptner 2004), the influence of history on the set up of local (self) government institutions after 1990 (Klimovský - Pinterič - Jüptner 2019), politicisation of municipalities (Ryšavý 2006) or individual characteristics of candidates in local elections and their influence on election results (Bernard 2012).

The theme of continuity and discontinuity in the development of political representation was discussed by Jaroslav Čmejrek and Jan Čopík (2009), who pointed out the significant change in the composition of the councils during the changes of political regime in 1918 and 1989, as well as 'local breakthroughs', such as extraordinary elections to the council. However, the topic of additional elections remains on the edge of researchers' interest and cannot be directly linked to existing theory or research on the Czech or foreign level. On the other hand, the possibility of managing one's own municipality is an important part of democracy. At the level of municipalities, especially in the smallest municipalities, people can directly influence the operation and direction of the municipality. However, in some municipalities people voluntarily give up the opportunity to manage their municipality. Municipalities without elected representatives subsequently stagnate in their development and provision of public services. Due to the high number of small municipalities in the Czech Republic, there is a high probability that this situation will occur in other municipalities in the future. The main goal of our study is to identify variables that are repeated within a selected sample of 16 municipalities in which additional elections took place in 2019. It is not clear whether this is a situation specific to each municipality or it is possible to identify a set of variables that lead to additional choices.

\section{When are there additional elections?}

Local elections are regulated by Act No. 491/2001 Coll. on elections to municipal councils in the Czech Republic. Since 1990, a proportional electoral system has been used in elections to municipal councils with free candidate lists, with the possibility of selecting individual candidates (Balík 2009). The electoral system itself is criticised because of its incomprehensibility and lack of clarity, as the voters often don't realise that the preferences of a particular candidate gives the primary voice to the party for which the person is standing (Lebeda 2009). 
If a municipal council is not elected, the Minister of the Interior has to declare repeated elections, repeated voting or additional elections within 30 days of the official announcement of results. The Minister of the Interior is obliged to convene additional elections in the case that 'the total number of candidates listed on all registered lists of candidates does not reach the absolute majority of the number of members of the municipal council to be elected or this number is less than five'. During a period when a municipal council has not been elected, municipal affairs are conducted by the appointed administrator (Act No. 491/2001). At the same time the performance of self-government stagnates, as the administrator is only tasked with maintaining the operation of the municipality.

\section{Theoretical background and determination of variables}

According to Vráblíková, there is no consensus among authors on what can be considered political participation (2008: 369). Why some people's political activity is higher than others can be broken down by the factors used to explain political participation. These are micro (individual characteristics), meso (social networks) and macro (national) variables (e.g. Vráblíková 2008: 373-4; Krishna 2002: 438). ${ }^{2}$

From the micro level we use the age of candidates, knowing that the youngest and oldest groups in society have less willingness to actively participate in political activities (Vráblíková 2009: 874; Armingeon 2007). Jaroslav Čmejrek also speaks of the distrust of candidates between the ages of 20-29 and 60 and older, despite the fact that they are the most represented people in society (2008: 73).

From the meso level, which we later divide into three types of mechanisms, we use the basic idea that persons involved in some associations are more politically involved (Vráblíková 2008: 378). Alexis de Tocqueville claimed that 'the technique of association becomes the mother of every other technique' (as quoted in Teorell 2003: 50). This can be linked to the first of the three types of mechanisms - civic skills ${ }^{3}$ (Teorell 2003; Verba et all. 1995). On the importance of facilitating political mobilisation, the second mechanism, Rosenston and Hansen claim that 'people participate in politics not because of who they are, but because of the political choices and incentives offered to them' (as quoted in Vráblíková 2008). It can be said that 'access to such networks increases the probability of being exposed to appeals for political participation' (Teorell 2006: 799-800; Verba et all. 1995). The third mechanism, the role of social capital, is predominantly associated with R. Putnam, who defines it as 'the relationship between individuals - social networks and the norms of reciprocity and trust that arise from them' (as quoted in Vráblíková 2008: 379).

2 For more details see, Vráblíková 2008.

3 'E.g. the ability to write official letters, organize meetings etc' (Vráblíková 2008: 378). 
In a study we also work with the typology of four local models (level of rivalry (formation of candidates lists) and format of the party system (plurality index)). For the purpose of this study, the most important is Model A: non-participatory model in which the lack of interest of inhabitants threatens the formation of their own council of municipality. According to the authors, these are municipalities in which there have been a high level of indebtedness and no one wants to be associated with these problems. For this reason, the same representants stand as head of the village for a long time. Typical for type A municipalities is a smaller number of candidates than the number of council members.

In the type B (apolitical-demarchist model) there are as many candidates (one political party) as there are seats in the council. It is therefore clear that the selected candidates will be elected as representatives of the municipality. Inhabitants are satisfied with the situation in the village and therefore they do not want to stand as a candidate in an election. But they are not indifferent to the independence of the municipality. The third model (type $\mathrm{C}$ - Cconsensual) is characterised by a larger number of candidates than the number of council members. A large number of parties are in an election as well as individual independent candidates. It is therefore predictable who will be elected as a representative of the municipality. The fourth model (type D - competitive) is characterised by a more intense rivalry between a larger number of parties (also traditional parliament party). At the same time, the number of candidates exceeds the number of elected seats. It is characteristic of a real political competition for a leading position within the municipality (for more details, see Čmejrek - Bubeníček - Čopík 2010: 155-166).

For the purpose of this work, it is verified whether the municipalities fall into the first type A using a simple calculation, where the number of candidates is divided by the number of elected seats (plurality index). If this number is less than one, it is a municipality that, according to the authors, tends to additional or recurring elections. In the case where the resulting number is equal to one, it is necessary to consider other variables (e.g. elites). When the resulting number is between one to two, it is a semi-pluralist case. In the case of a value higher than two, this is a pluralistic case (Čmejrek - Bubeníček - Čopík 2010: 156). The formation of candidate lists is verified by media analysis, which allows us to find out the pre-election atmosphere in the village. Specifically, this comes in the form of statements from Dan Rysavy and Michal Illsner (2006b), which talk about the potential problems small municipalities face in finding elites that follow the older generation and take over the reins in the leadership of municipalities. This unwillingness to participate in the running of the community is linked to both the contradictions on the personal level and the increase in bureaucracy, etc. At the same time, Ryšavý adds that in some villages the older generation prepares their successors and offers them a helping hand to the future (Ryšavý 2007: 123-4).

In connection with the phenomenon of continuity/discontinuity of the actions of persons in the municipal council, Čmejrek and Čopík concluded 
that after 1989 there was a low replacement of representatives, with a gap approaching $1 / 3$ of the council. According to the authors, the main reasons for this are the decreased willingness of members and non-party members to stand for a political party or the possibility that the candidate ranking on candidate lists was influenced by preferential votes, thus favouring one candidate (2009: 300-301). It can be assumed that often the same individuals are chosen for a longer period in municipal elections (Čmejrek - Bubeníček - Čopík 2010: 83, Hornek 2019: 236). This is why we use the elites variable. Other variables are associated with the willingness of members and non-party members to stand as a candidate in elections. We are interested in how many political parties created its candidate list for municipality elections, as we expect that a higher number of parties, as well as the number of associations, automatically brings a higher number of candidates and therefore reduces the risk of holding additional elections. According to Čmejrek, Bubeníček and Čopík, political participation cannot be directly separated from public life in municipalities with around 100 inhabitants. The existence of the association (beekeepers, the fire brigade, hunters, sports clubs or organisations (Sokol) etc.) is therefore crucial for the development of the village (2010: 83-5). The political sphere is also affected by personal disputes, local groups and families in the smallest municipalities (Keating 1995: 124-5, Illner 2006a: 22, Illner 2006b: 362-3). In a large municipality there are also more potential candidates and the public function is more prestigious (Illner 2006b: 362-3). According to Martins: 'the smaller the municipality, the greater the accessibility' between inhabitants and representants (1995: 453, Illner 2006b: 363). Inhabitants can also easily mobilise against the policy of the current representants (Newton 1982: 190, Swianiewicz 2002b: 10, Illner 2006a: 22). For this reason, we also use the 'number of candidates in the municipality' and 'size of the council and its transformation' variables.

Other variables can be combined with low councillor variability in terms of the chances of choosing new candidates in elections. Both Šedo and Bernard have shown that incumbents have a higher chance of re-election than newcomers (Bernard 2012: 635; Šedo 2009: 359). Those who have stood as a candidate but were not elected will be less willing to stand as a candidate again. This can be expressed by the "candidate fluctuation variable", which measures how many people did not repeat their candidacy in comparison with previous elections. At the same time, it is necessary to find out whether the conclusions of both authors also apply to the monitored municipalities. For this reason, the 'fluctuation of elected persons' variable is established.

The life of each municipality is closely linked to the political participation of their citizens. The basic indicator of political participation is voter turnout (Čmejrek 2008: 70; Čmejrek - Bubeníček - Čopík 2010: 77-8). In our study, we evaluate the "voter turnout variable" in terms of its variability and specificity within each municipality. The last variable we employ in our research is the 
financial situation in the municipality. The assumption is that in the event of a bad financial situation in the municipality (indebtedness), the willingness of citizens to lead the municipality decreases (Čmejrek - Bubeníček - Čopík 2010: 157-8, Hornek 2016: 102). If it turns out in the investigation that more municipalities have a problem with finances, the assumption can be confirmed.

\section{Data, variables and methodology}

Because of the absence of relevant information to clarify what may result in additional elections, the main goal of our study is to identify variables that are repeated within a selected sample of $16^{4}$ municipalities in which additional elections took place in 2019 (MICR, 2018). It is not clear whether this is a situation specific to each municipality or if it is possible to identify a set of variables that lead to additional choices 5 . For this purpose, a qualitative analysis is used that allows detailed insight into the life of each examined municipality. We also set the reference value at $50 \%$ for some variables, which is the value of a variable that is likely to be explanatory and must be taken into account when determining a given variable in a municipality.

We used data from the Czech Statistical Office and its website volby.cz, which provided information on local elections from 1994 to 2019. Specifically, voter turnout, number of voters, parties, candidates, age, candidacy or elected candidate (Volby.cz 2019) were used. Data on the municipal financial situation from 2010 to 2018 were obtained from the website of the Ministry of Finance of the Czech Republic and its information portal (Monitor 2019). A calculator for calculating municipal budget responsibilities until 2013 (Monitor. Universal calculator 2019) was used on the portal. We got information about organisations in the village from the website mistopisy.cz or from the website of the village (MPČR 2019). Direct insight into the life of the municipalities was obtained through a media analysis. Within the 16 municipalities where additional elections were held in 2019, the above variables could be examined from 1994 to 2019.

\section{Number of regular elections}

We observe whether there were early or additional elections in individual municipalities between 1994 and 2018.

4 A paradoxical situation occurred in the village of Němčovice (Rokycany), where Karel Ferschmann forgot to submit the candidate list for registration by the correct date. The reason for his omission was his participation at a children's camp (Pospišilová - Vildová, 22 November 2018). For this reason, Němčovice was excluded from the analysis.

5 However, this is a small number of municipalities. Many authors mention a high fragmentation of municipalities (over 6,000) and a low number of people living there (e.g. Balík 2009; Illner 2006a). Smaller municipalities are also in France, Slovakia, Germany, Greece, Iceland, Luxembourg, Spain, Switzerland and Hungary (e.g. Illner 2006b, Martins 1995). 


\section{The size of the council and its transformation}

In the period under review, we monitor the change in the size of the council (number of members) in order to see if a sudden increase in the number of members could cause the requirements of a candidate list to go unfulfilled. Elections held prior to 2018 in which the number of members increased compared to previous elections resulted in problems meeting the requirements for candidate lists.

\section{Number of candidate lists and associations}

According to the number of parties in the municipality, it is possible to determine whether there are at least two political camps and therefore a better chance of holding proper elections. With the increasing number of both parties and associations, there should be a higher chance of compiling at least one list of candidates which would be enough to fill the municipal council. At the same time, it is necessary to consider the size of the municipality when drawing conclusions, as some of the municipalities surveyed have about 100 inhabitants and we expect that there will be less chance of more candidate lists or associations being formed. We also consider the situation to be problematic when a majority or all traditional parliamentary political parties of municipality have ended in the same elections and citizens had to create new civic party/parties. The parliamentary political parties are characterised by good organisation and stability of members with a similar view of the village management (Čmejrek Bubeníček - Čopík 2010: 65-8: 70-71).

\section{Number of candidates in the municipality, plurality index and voter turnout}

The variable is measured by the total number of voters against the potential number of candidates, and also it is measured by whether we can determine a decreasing number of voters that would cause a reduction in the number of people able to actively participate in the election (Hornek 2019: 236, Illner 2006a: 21). Subsequently, the actual number of persons who participate in the elections is monitored in relation to the number of seats corresponding to the number of representatives in the municipality. The variable also takes into account whether all of the candidates were nominated according to the number of members on the municipal council or whether the number of candidates was smaller or larger (see above plurality index - the number of candidates is divided by the number of elected seats ${ }^{6}$. As evidenced by Dan Ryšavý and Pavel

6 The law regulates the candidacy of as many candidates as there are seats, with the difference that municipalities with a 7-member council (and less) may vote 1/3 more candidates (rounded down (Act 
Šaradín, the number of municipalities where the number of candidates did not exceed the number of elected seats has been decreasing since 1998 (2011: 28). Jaroslav Čmejrek also connects the choice of the exact number of persons according to the elected places with a democratic deficit (2013: 183).

Voter turnout is seen as an indicator of political participation by citizens and we observe whether there is a decreasing or increasing tendency. In our study we evaluate the voter turnout variable in terms of its variability within each municipality. The variability in the elections that are under scrutiny is important, especially in the 2014 elections, which were the last regular elections before the additional ones in 2019. However, the gradual decline in turnout is not important, but a sharp slump signalises a sudden loss of interest in voter participation (Čmejrek 2008, 70) as well as in the political life in the village. As documented by Čmejrek, Bubeníček and Čopík, small municipalities without city status reach significantly higher voter turnout in local elections and the decline there is much smaller than the national average (2010: 79-80). On this basis we conclude that if voter turnout falls rapidly, the willingness of citizens to stand as a candidate in elections is also declining, and in connection with other elements additional elections may occur.

\section{Age of candidates/non-stand as a candidate in the next elections}

We examine whether there is a certain age at which candidates will not stand as a candidate in the next election. Candidates are divided into 4 categories: 18 to 22 years, 23 to 45 years, 46 to 60 years and 61 and over. With these categories it is possible to determine which category in the municipality prevailed in individual electoral periods, as well as which representatives, by age, decided not to stand as a candidate in subsequent elections. However, for the non-stand as a candidate in the next elections variable, the age limit of the first category was shifted to 22 to 26 years, corresponding to the age of first-time voters after the four-year term.

\section{Elites}

We observe whether the sudden end of elites (stood as a candidate/elected in 3 consecutive elections) in the management of the municipality can be connected with additional elections. In case that a higher number of elites (reference value

No. 491/2001)). The law regulates the candidacy of as many candidates by the political party as there are seats, with the difference that municipalities with a 7-member council and less may has $1 / 3$ more candidates (rounded down (Act No. 491/2001)). Given the situation where 13 out of 16 investigated municipalities have 7-member and smaller councils, the given variable can still be considered relevant for determining conclusions. It is also important: 'If the total number of candidates listed on all registered candidate lists does not reach an absolute majority of the number of members of the municipal council to be elected, or is less than 5, elections are not held in this municipality' (Act. No. 491/2001). Municipalities with 5-member council, Děkov (since 2002), Kluky (2002 a 2006), Litichovice (2002, 2004, 2006 a 2010), Němčice (2019), Roblín (1994), Stř́tež (since 1998), Ždírec (2019). 
$50 \%$ ) decided not to stand as a candidate in the 2019 elections, we consider the variable to be relevant in the municipality. The variable primarily reflects if citizens of the municipality rely on the subsequent candidacy of elites and they do not have a need to engage politically.

\section{Fluctuation of candidates}

The variable is measured by the non-repetition of candidacy in comparison with the previous elections when the $50 \%$ threshold is taken as the reference value. One of the reasons that candidate lists were not filled is that previous candidates decided not to stand as a candidate again. A new candidate is also a person who previously stood as a candidate, but not in the last elections. In the second part, we examine how many candidates participating in specific elections had no experience with candidacy in previous elections (inexperienced candidates). The reference value is the $50 \%$ threshold, which sets the situation in which it was necessary to mobilise many people who have not yet had policy experience.

\section{Fluctuation of elected persons}

This variable covers the situation when we do not find elites in the village, but at the same time there has been an outflow of a larger number of elected representatives that need to be replaced. For elected persons, it is assessed whether the incumbents have defended their mandate or decided not to defend the mandate in subsequent elections. The reference value is the exchange of more than $50 \%$. The output of individual municipalities is considered to be the openness and permanence of the representative body. The openness of the representative body is high when existing representatives have not defended more than $50 \%$ of the mandates and there is a good chance of electing new candidates, which can motivate them to actively participate in elections. The permanence of the representative body is linked to the decision of the councillors not to stand as a candidate again in the next election. The problem occurs when more than $50 \%$ of the councillors do not want to defend their mandate and it is necessary to look for new candidates who would be willing to stand as a candidate for the next election. For municipalities where the number of elected persons is similar to the number of candidates, the variables (fluctuation of candidates and fluctuation of elected persons) will be relevant or irrelevant at the same time.

\section{Financial situation in the municipality}

According to Hronek, the most important financial indicators are budget lability and total liquidity for examining the financial situation in municipalities. 
On the other hand, these indicators only draw attention to possible risks in the management of municipalities and bad numbers do not automatically mean financial problems of the municipality. For this conclusion a detailed financial audit is required (Hornek 2016: 88-89). In our study we used these indicators in the municipality from 2010 to 2018 . The first indicator, the budget liability rule, is calculated from 2013 to 2018. It is based on the assumption that a municipality, a city or a county manages in such a way that the debt level does not exceed $60 \%$ of the average annual income calculated over the last four years. If the municipality does not comply, it must reduce its excessive liabilities by at least 5\% per year. Total liquidity is measured since 2010 (it determines the ratio by which the municipality is able to cover its short-term liabilities). The problem value is one or less.

\section{Media Analysis}

In the empirical part we analysed media outcomes in which mayors, members of the council and residents of the municipalities gave reasons why a sufficient number of candidates did not participate in the October 2018 elections. Their statements are compared with the data obtained from the history of local elections in municipalities as well as the facts stated by Ryšavý and Čmejrek, Bubeníček and Čopík (four local models).

For media analysis we used the Anopress database service of the Anopress IT Company. The key words used were the names of specific municipalities, with a search period of August 1, 2018 - February 26, 2019. This is due to the fact that, at the beginning of this period, information began to appear in the media space that in some municipalities local elections were unlikely to take place (on 5 and 6 October 2018). All media outputs that were searched by the database were analysed. There were about 120 relevant contributions concerning the local elections; some of them were overlapping, listed in more cases

In the case of municipalities for which the media outputs were not numerous, supplementary searches were used, where the name of the former or current mayor was given as the key word. It was not possible to use media analysis for the village of Kluky, because the municipality name means 'boys'. The necessary information was obtained by telephone conversation with the mayor of the village.

\section{Results}

In the following section, the results associated with each variable are presented. The basic summary of the results is provided in Table 1, which in a simple way, i.e. Yes (the variable has a meaning) and No (the variable has no meaning) allows the reader to see the relevance of each variable related to the municipality. 


\section{Table 1: Variables within municipalities ${ }^{7}$}

\begin{tabular}{|c|c|c|c|c|c|c|c|c|c|c|c|c|c|c|c|c|}
\hline Variables & 1 & 2 & 3 & 4 & 5 & 6 & 7 & 8 & 9 & 10 & 11 & 12 & 13 & 14 & 15 & 16 \\
\hline The si & o & no & no & no & no & no & no & no & no & no & no & no & no & no & no & \\
\hline Vote & 0 & no & no & no & no & no & yes & no & no & yes & no & no & no & yes & yes & \\
\hline & no & yes & yes & no & no & yes & yes & yes & no & no & yes & no & no & no & no & \\
\hline $\begin{array}{l}\text { The tota } \\
\text { voters }\end{array}$ & no & no & no & no & no & no & no & no & no & no & no & no & no & no & no & \\
\hline Num & no & no & no & no & no & no & no & no & no & no & no & no & no & yes & no & \\
\hline Age o & no & no & no & no & no & no & no & no & no & no & no & no & no & no & no & \\
\hline $\begin{array}{l}\text { Age of candidates/non- } \\
\text { stand as a candidate in } \\
\text { the next elections }\end{array}$ & no & no & no & no & no & no & no & no & no & no & no & no & no & no & no & \\
\hline Elites & yes & yes & yes & yes & yes & yes & no & no & yes & no & no & no & yes & no & no & \\
\hline Pluralit & 0 & no & no & no & no & no & no & no & no & no & no & no & no & yes & no & \\
\hline Personal disputes & yes & yes & no & no & yes & yes & yes & no & yes & yes & no & no & yes & no & yes & \\
\hline $\begin{array}{l}\text { Number of regular } \\
\text { elections }\end{array}$ & yes & no & no & no & no & no & no & no & yes & no & no & no & no & no & yes & \\
\hline
\end{tabular}

\section{Fluctuation of candidates}

\begin{tabular}{|l|l|l|l|l|l|l|l|l|l|l|l|l|l|l|l|l|}
\hline $\begin{array}{l}\text { Non-stand as } \\
\text { a candidate again }\end{array}$ & yes & yes & yes & yes & yes & yes & no & yes & yes & no & yes & yes & yes & yes & no & yes \\
\hline $\begin{array}{l}\text { Completely new } \\
\text { candidates }\end{array}$ & yes & yes & no & yes & yes & yes & no & yes & yes & no & yes & yes & no & yes & yes & yes \\
\hline
\end{tabular}

\section{Fluctuation of elected persons}

\begin{tabular}{|l|c|c|c|c|c|c|c|c|c|c|c|c|c|c|c|c|}
\hline Non-defend mandate & yes & yes & yes & yes & yes & yes & yes & yes & yes & yes & yes & yes & yes & yes & yes & yes \\
\hline $\begin{array}{l}\text { Non-stand as } \\
\text { a candidate again }\end{array}$ & yes & yes & yes & yes & yes & yes & no & yes & yes & no & no & yes & yes & yes & no & yes \\
\hline
\end{tabular}

Financial situation in the municipality

\begin{tabular}{|l|l|l|l|l|l|l|l|l|l|l|l|l|l|l|l|l|}
\hline $\begin{array}{l}\text { The budget liability } \\
\text { rule }\end{array}$ & yes & no & yes & no & no & yes & no & no & no & no & yes & no & no & no & yes & no \\
\hline Total liquidity & no & no & no & no & no & no & no & no & no & no & no & no & no & no & no & no \\
\hline
\end{tabular}

Source: own drawing. Data: Volby.cz 2019; Monitor 2019

7 Municipalities (their district) are sorted: 1) Děkov (Rakovník), 2) Dlouhá Lhota (Blansko), 3) Hodějice (Vyškov), 4) Horšice (Plzeň-Jih), 5) Kadlín (Mělník), 6) Kbelnice (Jičín), 7) Kluky (Mladá Boleslav), 8) Lipovec (Blansko), 9) Litichovice (Benešov), 10) Němčice (Strakonice), 11) Roblín (Praha-Západ), 12) Skomelno (Rokycany), 13) Střítež (Ždár nad Sázavou), 14) Tatobity (Semily), 15) Víska u Jevíčka (Svitavy), 16) Ždírec (Havlíčkův Brod). 
Municipalities in the study do not reach more than 500 inhabitants $^{8}$. It is therefore clear that the additional elections concern municipalities with a smaller population. For this reason, it is possible to use the definition of municipalities according to the four local models set by Čmejrek - Bubeníček - Čopík (2010: 156). The results show that the plurality index was greater than 1 in most municipalities for all election periods (without elections in 2018). In the three municipalities of Děkov, Hodějice and Lipovec it reached well over two, which was caused by a larger number of parties and movements (two and more). On the other hand, traditional parties ČSSD ${ }^{9}$ and KDU-CSL ${ }^{10}$ didn't have a candidate list (on the contrary, KSČM ${ }^{11}$ and the Mayors and Independents party had a candidate list since 2010 and 2014, respectively) in Hodějice in the additional election and the plurality index decreased from four to two. Also, traditional parties ČSSD, KDU-CSL and KSČM did not have candidate list in Lipovec in the additional election, but the plurality index remained the same. These political parties were replaced by the independent/civic parties in both municipalities in the additional election. In the municipalities of Kluky and Víska u Jevíčka (before the additional elections in 2014), the value of the plurality index was equal to one. In the village of Kluky, this could be due to the participation of one movement in the election in 2014, because normally two movements were in the 2006 and 2010 elections. In the village of Víska u Jevíčka, the reason could be the end of the ODS party, which had its candidate list in the elections in 1998 and 2006. In the village of Dlouhá Lhota, the value of the plurality index was equal to 1 in the last three elections preceding the additional elections (also in 1998) and could have been caused by the departure of the KDU-ČSL and KSČM parties and its replacement by the Association of Independent Candidates. At the same time, it is evident that only in the municipalities of Tatobity and Ždírec the value of the plurality index reached a value of 0.7 in 2014, which means a smaller number of elected persons than the number of seats in the municipal council and a potential problem for the municipality's own management. At the same time, the candidacy of independent individual candidates in most of the examined elections and the subsequent establishment of the Association of Independent Candidates for additional elections is typical for both mentioned municipalities. At the same time, it was possible to observe the inertial tendency in the value of plurality index in within the examined elections in all municipalities. Only in the municipality of Kadlín did the plurality index have a declining

8 Only Hodějice and Lipovec had significantly more than 500 inhabitants (around 900 in 2018). Only the village of Tatobity had over 400 inhabitants, and the village of Horšice had over 300 inhabitants. Seven municipalities had less than or just over 100 inhabitants. The remaining five municipalities had less than 200 inhabitants.

9 Czech Social Democratic party.

10 Christian and Democratic union - Czechoslovak People's Party.

11 Communist Party of Bohemia and Moravia. 
tendency, but in the elections in 2014 it had a value of two because two opposition independent political parties were formed within the municipality and it is possible to speak of a more significant plurality within the municipality. The plurality index also reached a value of one in six municipalities in the 1994 elections, which can be explained with the beginnings of the formation of a local party system (Čmejrek - Bubeníček - Čopík 2010: 158). When we focus on compiling candidate lists before the regular elections in 2018, which did not take place in these municipalities, we find recurring trends that may contribute to understanding which municipalities may have a potential problem securing a sufficient number of candidates/representatives.

\section{Relevant variables}

\section{Elites}

The number of elites in the village ranged from $15 \%$ to $26 \%$ of all candidates, except for the municipality of Litichovice. For the purpose of this work, however, it was important to determine whether the sudden end of the so-called elites could be linked to the holding of additional elections. From the data presented, it is clear that the possibility of additional elections can be directly linked to the sudden end of the so-called elites. Results in eight out of sixteen investigated municipalities say that at least $1 / 3$ of the elites still stood as a candidate in 2014, but not in 2019, so the sudden end of the elites may have been caused by the additional elections. This confirms the authors' opinion that small villages have a problem finding new representatives due to personal disputes (see media analysis), despite the offer by older representatives train a new generation of representatives (Čmejrek - Čopík 2009: 300-301, Čmejrek - Bubeníček - Čopík 2010: 83, Illner 2006b, Ryšavý 2007: 123-4). The importance of the end of the elites is emphasised by three other variables: Non-stand as a candidate again, How many people did not defend the mandate and Failure to defend the mandate. In connection with the end of the elites and other councillors, or a more significant change of candidates may cause a situation where enough new candidates/representatives cannot be found in the municipality. At the same time, in villages where the same people regularly defend their mandate, a situation typical of a village type $\mathrm{B}$ arises. Citizens do not want to stand as a candidate, as they rely on existing representatives (Čmejrek - Bubeníček - Čopík 2010: 158).

\section{Non-stand as a candidate again}

In all 16 municipalities, six relevant elections (Děkov and Litichovice, seven elections) were examined in which it was possible to calculate the replacement of candidates compared to previous elections. The data show that in thirteen out of sixteen municipalities the candidates were replaced by more 
than $50 \%$ in three or more elections. This means that more than $50 \%$ of new people have always participated in the electoral struggle. In addition, for the 10 municipalities, the candidates' largest changes were due to the additional elections in 2019. Thus, a large number of candidates can be one of the factors causing the non-inclusion of the candidate list and therefore the additional elections.

\section{How many people did not defend the mandate}

For all sixteen municipalities, six relevant elections (Děkov and Litichovice, seven elections) were examined in which the percentage of cases where councillors did not defend their mandate could be calculated. It is evident that in four out of sixteen municipalities there were three or more cases where more than $50 \%$ of the councillors did not defend their mandate. It is important for the purpose of the work that in twelve out of sixteen municipalities more than $50 \%$ of former representatives did not defend their mandate in the additional elections in 2019. For five municipalities it was more than $70 \%$, which can be connected with a significant replacement of the entire representative body. The variable can be one of the explanatory reasons why additional elections were held in the municipalities.

\section{Failure to defend the mandate}

The results show that none of the sixteen municipalities saw a greater drop in previously successful candidates if they decided to defend their mandate. From this it can be concluded that incumbent candidates have a strong position within the municipality and have a great chance of re-election (Bernard 2012: 635; Šedo 2009: 359) and, conversely, the new candidates have less of a chance of being elected and are therefore not motivated to stand as a candidate at all. In the case that a larger number of members of the council with a minimum variation decide not to stand as a candidate, it may suddenly be a problem to find new candidates who would like to run for the town office because they do not feel they have a chance of being elected. So, the variable is relevant.

\section{Personal disputes}

From the media analysis results, it can be seen that in addition to confirming the significance of the variables 'elites' and 'non-stand as a candidate again in 2014', which are often associated with personal reasons (more time for family, exhaustion, health) ${ }^{12}$, it is possible to determine another variable called personal

12 It was about Děkov (Elsnic, October 6, 2018), Dlouhá Lhota (Právo, 5 October 2018; Blanenský deník, 2018), Hodějice (Gajdošíková and Sapík, 18 August 2018; Baroch, 27 August 2018), Horšice (Štemberová, 4 
disputes. At the same time, it is clear from the results of the media analysis that the surveyed municipalities fall into the type A or B category (in terms of drawing up candidate lists), as citizens do not want to stand as a candidate or they rely on existing representatives. This variable has been identified in 10 out of 16 municipalities, be it representatives or citizens, and in many cases, disputes have been a relevant reason that have forced former deputies to leave politics.

In Kbelnice there was an additional election despite the fact that former representatives 'agitated' residents through notifications to mailboxes and also promised to help new councillors (Fremuth, 5 October 2018). Mayor Michalčíková mentioned the lack of interest in events organised by the town hall. She said: 'everyone closes their entry gates door, and no one cares about situation in the village today' (Kovářová, 16 August 2018). The same situation is seen in Dlouhá Lhota, where residents said: 'I don't know, I don't have time for it' or 'Well, I'm not skilled enough for it' (Žítková, 5 October 2018). According to former mayor Michaela Gregorová (Kadlín), additional elections were caused by 'communication noise' among potential candidates (Votruba, October $5,2018)$. The situation in the village was also worsened by the immigration of new people who wanted to lead the village or the relationship of the mayor's son with the daughter of the opposition representative (Ševela, October 12, 2018). Thus, immigration of new persons may not always help the future administration of the municipality, as Čmejrek, Bubeníček and Čopík said (2010:157-8). Residents also said it was an ungrateful job they had no time or nerves to do (Ševela, October 12, 2018).

In Děkov, the situation had even gone so far that a criminal complaint was filed at Závorová (Elsnic, 6 October 2018; Nič Husárová, January 28, 2019). The same situation happened with Mayor Štourač in Střítež (Mašová, September 27, 2018). There was another problem in Střítež where the municipality lost ownership of the ruins of castle Bukov-Lísek, resulting in a loss of about CZK 300,000, and problems with the access road and land use plan (Laudin, October 5, 2018)). Mayor Semiánová (Kluky) said: 'There are discrepancies among inhabitants in the municipality, especially with one of the notoriously complaining citizens'. According to the mayor, this may cause difficulties in setting up candidate lists for the next election, as the new councillors need time to acclimatise, because they have not worked for the community for a long time (Semiánová 2019). According to former Mayor Miroslav Čepický (Horšice), there is no party or association of independent candidates, which may have contributed to the fact that citizens could vote only at the end of January 2019 (Štemberová, October 4, 2018). In Víska u Jevíčka, according to the residents, it is partly about the stubbornness

October 2018), Kbelnice (Fremuth, 2 October, 2018; (Kovářová, 16 August 2018), Kluky (Semiánová 2019), Lipovec (Svoboda, August 13, 2019), Skomelno (Meissnerová: 22. 8. 2018), Stř́tež (Mašová, 27 September 2018), Víska u Jevíčka (Mladá fronta Dnes, August 11, 2018), Ždírec (Laudin, 5 October 2018). 
of the locals, because some of them stand by their own opinions and do not take into account the views of their opponents. Others said there was a division into different family clans in the village (Hofmanová, September 7, 2018).

People experienced somewhat of a misunderstanding and did not realise the necessity of resolving the situation after the announced resignation of Mayor Kopřiva in Lipovec (Hřebíková, 25 January 2019; Osouch, 22 November 2018). In Litichovice people rely on the fact that the current representatives will continue their work (Kellner, 26 October 2018), as do those in Roblín (Gavenda, September 30, 2018; Česká televize, 21 November 2018). The former mayor in Roblin said that another problem could have been the tightening of the conflict of interest act and related criminal and property liability, as well as the mayor and his representative's obligation to grant income and property in the public register (Právo, August 23, 2018). The same opinion is held by Mayor Dobrovolný (Ždírec (Laudin, October 5, 2018)). Despite these reasons, a candidate list under the leadership of Mayor Dobrovolný was ready to be registered for the autumn 2018 election, but unfortunately one of the members resigned her candidacy a few days before her appointment (Saadouni, August 2, 2018).

A seemingly paradoxical situation (typical for type B) occurred in the village of Němčice when none of the above-mentioned citizens were willing to take the post of mayor after the elections (Orholz, August 16, 2018). In the village of Tatobity, Mayor Malá said that several former representatives wanted to stand as a candidate again, but the deadline for submitting candidate lists had expired in the meantime (Fogl, September 25, 2018).

\section{Potential variables}

The variables listed below did not prove to be relevant for most of the municipalities surveyed but may contribute to additional elections in individual municipalities.

\section{Number of candidate lists/associations}

In four out of sixteen municipalities, in at least four out of seven or eight ${ }^{13}$ elections, stood several independent candidates from only one party (which is a sign of village type B). For six out of sixteen municipalities, the candidacy of an independent candidate was typical (which is a sign of village type $C)^{14}$. In the rest of the municipalities, there were at least two parties that ran for a seat in the municipality (which is a sign of village type $C$ or $D$ ). Seven villages have a church and ten municipalities have a pub; these are places that increase the chances of active involvement in the political life of the village. Similarly, there

13 In Litichovice and Děkov there were 8 elections.

14 One independent party was created for an additional election in these municipalities (4 of 6). 
were sports associations in four municipalities, and six villages had civic associations. On the other hand, the most critical situation occurred in the villages of Roblín and Kbelnice, where there was only a pub and citizens were standing as individual independent candidates for most of the time. In Kadlín (with a church and a non-functioning pub) and Kluky there were important political parties, but no association. On the other hand, one movement had a candidate list in the election in the village Kluky in 2014, even though there were normally two movements in the elections of 2006 and 2010. Other villages (twelve) had perhaps the most important kind of association for social life: the fire brigade ${ }^{15}$ (MPČR 2019). In three municipalities (Hodějice, Lipovec and Dlouhá Lhota) all or most of the traditional parliamentary parties didn't have a candidate list in the additional elections, which means a more significant intervention in the normal operation of the municipality when compiling lists of candidates. It is evident from the results that this variable did not cause additional elections in ten villages.

\section{Voter turnout}

A possible explanatory variable causing additional elections is voter turnout. It was in five of sixteen municipalities that the voter turnout in the election in 2014 (Víska u Jevíčka in the election in 2010) was the lowest since 1994, despite the fact that the number of voters has been growing. It is true that the decreasing trend in voter participation is nothing unusual, since after the fall of the communist regime the voter turnout in most municipalities was at its maximum and in the following years it slowly declined (Vráblíková 2009: 868; Čmejrek - Bubeníček - Čopík 2010: 79). On closer inspection, however, we find that in four out of sixteen municipalities the decline was sharp, as turnout declined by at least $16 \%$ and at most by $26.5 \%$, although it was high in previous elections. When comparing the average turnout according to the size of the municipality in terms of the number of voters (Table 2), a gradual decline in turnout can be observed in all types of municipalities, which supports the conclusions on the issue of a sharp decline in turnout as one of the elements causing additional elections.

15 The Děkov had listed on its website Myslivecký spolek Diana Horšice (Tolarová), the Lipovec had listed on its website Spolky a organizace (Obec lipovec) or pub in Kadlín (Gregorová 2018). 
Table 2: Average voter turnout by municipality size (number of voters) ${ }^{16}$

\begin{tabular}{|c|c|c|c|c|}
\hline Year & $\mathbf{1}$ to $\mathbf{1 0 0}$ voters & $\mathbf{1 0 1}$ to $\mathbf{2 5 0}$ voters & $\mathbf{2 5 1}$ to $\mathbf{5 0 0}$ voters & 501 to 1000 voters \\
\hline 1994 & $888(87.57 \%)$ & $1899(81.53 \%)$ & $1459(77.08 \%)$ & $995(74.92 \%)$ \\
\hline 1998 & $856(80.29 \%)$ & $1852(72.39 \%)$ & $1503(65.96 \%)$ & $1037(63.14 \%)$ \\
\hline 2002 & $808(78.09 \%$ & $1834(70.84 \%)$ & $1519(65.62 \%)$ & $1065(62.91 \%)$ \\
\hline 2006 & $764(75.30 \%)$ & $1802(67.80 \%)$ & $1546(63.26 \%)$ & $1095(59.92 \%)$ \\
\hline 2010 & $717(74.01 \%)$ & $1750(67.33 \%)$ & $1541(63.70 \%)$ & $1144(61.07 \%)$ \\
\hline 2014 & $675(71.47 \%)$ & $1726(65.13 \%)$ & $1541(61.44 \%)$ & $1171(58.10 \%)$ \\
\hline 2018 & $667(71.02 \%)$ & $1706(64.82 \%)$ & $1544(60.45 \%)$ & $1187(57.72 \%)$ \\
\hline
\end{tabular}

\section{Age of candidates/non-stand as a candidate in the next elections}

It is not possible to determine with certainty from the data obtained whether the candidate's age is important in his/her subsequent candidacy, as candidates of different ages did not stand as a candidate again in individual municipalities. At the same time, however, it can be concluded that the so-called first-time voters (first category) and fourth-category (aged 61 and older) people, due to their limited frequency as candidates, are more prone not to repeat their candidacy in subsequent elections. At the same time, however, it cannot be said that people over the age of 61 will not automatically stand as a candidate for the next election, because in surveyed municipalities we can find candidates over the age of 70 who participated in the next elections. Thus, the age of candidates is rather one of the reasons why people choose not to stand as a candidate again but does not directly cause additional elections.

\section{Number of regular elections}

In the village of Víska u Jevíčka (2015) and Litichovice (2004-5) there were additional elections and in the village of Děkov (2015) early elections. Thus, one of the aspects of the type A local model is fulfilled in these municipalities (Čmejrek - Bubeníček - Čopík 2010: 157).

16 For each voter turnout, the number of municipalities is written. 


\section{Irrelevant variables}

\section{The size of the council and its transformation}

There was no increase in the number of council members in any of the monitored municipalities before the regular elections in 2018. On the contrary, the number of members was reduced in three municipalities. The fact that there was no candidate list in the municipality could not be influenced by the increased number of members in the municipal assembly.

\section{Total number of voters}

The number of voters, i.e. persons potentially able to lead the municipality, in all municipalities, for the monitored periods, increased or did not change. Therefore, a total number of voters cannot be an explanatory variable.

\section{Completely new candidates}

Regarding the candidacy of the inexperienced people in the sixteen investigated municipalities, it is clear that in twelve of them more than $50 \%$ of inexperienced candidates participated in the additional elections in 2019. In half of the cases, this figure was more than 70\%. In Víska u Jevíčka a similar element before the additional elections in 2015 can be seen, when more than $50 \%$ of the candidates were completely inexperienced. This suggests that the number of newcomers may be one of the consequences of additional elections, but it cannot cause additional choices. That statement corresponds to the claims of Čmejrka and Čopík, who combined the significant replacement of candidates with the so-called local breakthrough, which surely are additional elections (Čmejrek - Čopík 2009: 299). The citizens of these municipalities are not indifferent to the development of the municipality (which is a sign of village type B).

\section{Financial situation in the municipality - The budget liability rule}

The variable has long been unsatisfactory for four municipalities, two of them exceeded $100 \%$, which pointed to the high indebtedness of municipalities. The reason for that is the construction of a wastewater treatment plant in Hodějice (Jihomoravský kraj: July 28, 2016), sewerage in Kbelnice (Fremuth October 5), water supply in Roblín (Obec Roblín) and Víska u Jevíčka (obec Víska u Jevíčka). According to Hornek, these causes of indebtedness are not so problematic (see Hornek 2016: 100-101). In addition, none of the municipalities had a problem with the liquidity ratio. The municipalities were therefore not over-indebted and the elected representatives could properly administer the municipality (even though they had to repay the loan (Hornek 2016: 102)). 


\section{Conclusion}

The issue of additional elections has not yet been sufficiently addressed, so the main goal of the article was to define a set of variables that can be associated with additional elections. The main reason was the fact that in the case of a non-election of the municipal council, such a municipality is led by an administrator, who only keeps the municipality in operation but cannot further develop it. As part of the qualitative analysis, we came to the conclusion that individual municipalities can be classified according to some variables into one of four types of local models. However, in terms of the plurality of individual municipal systems, only two municipalities fell into the type A category, so the plurality in most municipalities was sufficient for type B to C or D.

Following the way in which candidate lists are formed in the municipality, the main problems turned out to be the end of elites, non-stand as a candidate again, and failure to defend the mandate, which is associated with a greater rotation of candidates, or the end of elites which no one replaced (caused by health problems, personal disputes, bureaucracy, long office management, etc.). Citizens also did not agree on the composition of the candidate lists due to personal disputes, or they did not to realise the magnitude of the situation and relied on existing representatives. The variable of Failure to defend the mandate also contributed to this situation, as the new candidates in the elections did not defeat these elites. So, in the municipalities, a situation has arisen that is associated with a type B municipality, i.e. citizens rely on current representatives to continue to run the office and thus loses interest in running the municipality, which can be also associated with a type A municipality, which the authors associate with holding additional elections. On the other hand, there is a variable (completely new candidates) against the assertion that municipalities fall into category type A. As there are many newcomers in the village who are not indifferent to the future of the village.

Voter turnout in the municipality proved to be a potential variable, because four municipalities had a significant decrease of voter turnout in the 2014 elections, which means a certain loss of interest in politics in the municipality. At the same time the additional or early elections in the history of three municipalities point to existential problems in the past. Conversely, the age of the candidates may have played a role in their decision to remain in politics. On the other hand, it was not possible to find an age limit at which individual elites are likely to leave politics. For Number of candidate lists / associations variable it was not possible to find any association that would shape life in the municipality only in the two municipalities. The question thus remains who is a member of these associations? Old representatives or the new generation? On the other hand, traditional parliamentary parties did not have a candidate list for the first time in the additional election in three municipalities and citizens had to form new 
civic parties, which possibly influenced creating candidate lists in these municipalities. The size of the council, the total number of voters or, somewhat surprisingly, the financial situation in the municipality can be described as irrelevant variables. This is despite the fact that Čmejrek - Bubeníček - Čopík (2010: 157) claim that a poor financial situation is one of the basic indicators of a type A municipality.

The work thus proves that the additional elections are mainly due to bad interpersonal relationships and the departure of a larger number of former politicians, whether elites, councillors or candidates in elections. A more significant reduction in voter turnout, which means the loss of interest in the policy of the municipality or the demise of some organisation or parliament parties caring for the cultural life of the municipality can also cause additional elections. At the same time, additional elections may occur even in the event of a failure of the human factor, as in the case of the municipality of Nermčovice.

As part of further research, it would be necessary to examine other municipalities in which there were additional elections and to confirm or refute the conclusions that we present. According to the plurality index, municipalities can be classified mainly as type B and C municipalities (only two municipalities were type A). For the compilation of candidate lists the most important variables are the departure of elites and other politicians and the reluctance of the population to stand as a candidate instead of departing representants. The main reason was personal disputes and not realising the seriousness of the situation (type B municipalities, eventually A). It is not also clear whether significant financial problems without other factors are sufficient for additional elections, as well as whether the non-existence of an association or the end of traditional political parties in the municipality is a decisive variable. In the event that the conclusions we present are confirmed, is there a risk of additional elections in other municipalities during the generational change of representants? Is this a established situation or is it an element that is typical of a certain segment of small municipalities?

\section{References}

Act No. 491/2001 Coll., Of 6 December 2001 on elections to municipal councils and on amendments to certain acts., available at https://www.zakonyprolidi.cz/cs/2001-491 (8 May 2019).

Adámková, Michaela (2018): Obce, kde se nevolí. ZAK TV: Zprávy ZAK (October 4), available at https://www.zaktv.cz/archiv/zpravy/3116.html?stranka=62 \& stranka=63 (8 May 2019).

"Additional election." Česká televize: Události, November 21, 2018, available at https://www. ceskatelevize.cz/porady/1097181328-udalosti/218411000101121/ (8 May 2019). 
Armingeon, Klaus (2007): Political Participation and Associational Involvement, in W. van Deth Jan, Ramón Montero José, Westholm, Andreas. (eds.). Citizenship and Involvement in European Democracies. A Comparative Analysis, 358-384, London, New York: Routledge.

Balík, Stanislav (2009): Komunální politika: obce, aktéři a cíle místní politiky. Praha: Grada Publishing.

Baroch, Pavel (2018): Sedmnáct obcí bez voleb. Týden (27 August).

Bernard, Josef (2012): Individuální charakteristiky kandidátů ve volbách do zastupitelstev obcí a jejich vliv na volební výsledky. Czech Sociological Review 48 (4): 613-640.

Burešová, Barbora - Balík, Stanislav (2019): The Discussion of Possible Savings based on the Efficiency Argument in the Smallest Municipalities? The Case Study of the Vysočina Region. Politics in Central Europe, Sciendo (De Gruyter Open), 15 (2): 333-354.

Čmejrek, Jaroslav (2008): Obce a regiony jako politický prostor. Praha: Alfa publisher.

Čmejrek, Jaroslav - Čopík Jan (2009): Kontinuita a diskontinuita ve vývoji lokální politické reprezentace. Acta Politologica 1 (3): 284-304.

Čmejrek, Jaroslav - Bubeníček Václav - Čopík, Jan (2010): Demokracie v lokálním politickém prostoru: specifika politického života v obcích ČR. Praha: Grada.

Čmejrek, Jaroslav (2013): Demokratický deficit v lokálním politickém prostoru ČR: možnosti a meze analýzy. Acta Politologica 5 (2): 178-186.

Data file (excel) in email from Ondřej Procházka from Czech Statistical Office, June 6, 2019.

Elsnici, Miroslav (2018): Děkovští přišli o mandáty. Obec řídí úřednice z ministerstva vnitra. Rakovnicky.denik.cz (6 October), available at https://rakovnicky.denik.cz/zpravy_region/dekovsti-prisli-o-mandaty-obec-ridi-urednice-z-ministerstva-vnitra-20181006.html (May 8, 2019).

Fogl, Adam (2018): Tatobity: vesnice roku, v níž se začátkem ř́ína volit nebude. Týdeník Liberecko (September 25), available at https://liberecky.denik.cz/zpravy_region/tatobity-vesnice-roku-ve-ktere-tento-vikend-lide-volit-nebudou-20181003.html (8 May 2019).

Fremuth, Jiří (2018): V Kbelnici volby nemají. Vesnici nepotopíme, slibuje končící starostka. Mladá fronta Dnes: Hradecký kraj (5 October), available at https://www.idnes.cz/hradec-kralove/zpravy/komunalni-volby-2018-kbelnice-jicinsko-kandidatka.A181002_430181_hradec-zpravy_the.

Fremuth, Jiří (2018): Kde vzít kandidáty? Nejsou. Mladá fronta Dnes: Hradecký kraj (2 October).

Gajdošíková, Vlasta - Sapík, Lukáš (2018): Bez jediného kandidáta. Nejméně v 17 českých obcích v říjnu nebudou komunální volby. iROZHLAS.cz (8 August), https://www.irozhlas.cz/zpravy-domov/hodejice-komunalni-volby-bez-kandidata_1808181945_dbr (8 May, 2019).

Gavenda, Jaroslav (2018): Starosta zapomněl na kandidátku. V dalších obcích zase nikdo nechce na radnice. Minimálně v 17 vesnicích nebudou volby. Seznamzpravy.cz (30 September), availabel at https://www.seznamzpravy.cz/clanek/starosta-zapomnel-na-kandidatku-v-dalsich-obcich-zase-nikdo-nechce-na-radnice-minimalne-v-17-vesnicich-nebudou-volby-56531 (8 May 2019).

Gregorová, Michaela (2018): Obec Kadlín zveřejňuje svůj záměr pronajmout majetek obce Kadlín - nebytové prostory. http://www.kadlin.cz/assets/File.ashx?id_org=15614 \& id_dokumenty=2863 (8 May 2019). 
Hodějice a Kobeřice mají nové čističky odpadních vod. Jihomoravský kraj (28 July 2016), available at https://www.kr-jihomoravsky.cz/Default.aspx?ID=313434 \& TypelD=2 \& fbclid=lwAR00buq CjQEglbCPIE7LuKi3e6jPuDXm6O2eF7_-cHOmx-Lf05y125XN1sA \& origin=mobile (8 May 2019).

Hofmanová, Věra (2018): Nezájem o práci zastupitele. Česká televize: Události v regionech - Praha (7 September), available at https://www.ceskatelevize.cz/ivysilani/10118379000-udalosti-vregionech-praha/218411000140907-udalosti-v-regionech (8 May 2019).

Hornek, Jakub (2016): Politické dopady zadlužování malých obcí v České republice: případová studie Karlovarského kraje 2010-2014. Praha: Sociologické nakladatelství (Slon), Studie.

Hornek, Jakub (2019): Endangered European Municipalities: Primary Systematization of the Problem and Political Impacts. Politics in Central Europe, 15 (2): 219-256.

Hřebíková, Dominika (2019): Dodatečné volby do zastupitelstva. Česká televize: Události, (25 January), available at https://www.ceskatelevize.cz/ivysilani/1097181328-udalosti/219411000100125 (8 May, 2019).

Illner, Michal (2006a): Velikost obcí, efektivita jejich správy a lokální demokracie. In Vajdová, Zdenka. - Čermák, Daniel. - Illner, Michal. Autonomie a spolupráce: důsledky ustavení obecního ř́zení v roce 1990, 15-26, Praha: Institute of Sociology, Czech academy of science.

Illner, Michal (2006b): Jsou venkovské obce v ČR př́liš malé? In Majerová Věra (ed.). Sborník příspěvků z mezinárodní conference Venkov je náš svět, 357-368, Český krumlov, 1-3 března 2006, Praha: Provozně ekonomická fakulta České zemědělské university v Praze.

In a telephone conversation to Mayor Zdenka Semiánová from village Kluky, 29 May 2019.

Jaroš, Bronislav - Balík, Stanislav (2018): Nové komunální volby v ČR 2002-2017: blokující menšiny?. Acta Politologica 10 (1): 139-152.

Jüptner, Petr (2004): Komunální koalice a politické modely. Czech Political Science Review 10 (2): 81-101.

Jüptner Petr (2012): Přímá volba starostů v evropské komparaci a české diskusi. Acta Politologica 4 (3): 232-245.

Keating, Michael (1995): Size efficiency and Democracy: Consolidation, Fragmentation and Public Choice, in Judge David, Stoker Gerry, Wolman Harold (eds.). Theories of Urban Politics, 117-134, London: Sage Publications.

Kellner, Zdeněk (2018): Litichovickým nepomáhá starosta, ale správce z ministerstva. benesovsky. denik.cz (October 26), avalialbe at https://benesovsky.denik.cz/zpravy_region/litichovickym-nepomaha-starosta-ale-spravce-z-ministerstva-20181026.html (8 May 2019).

Klimovský, Daniel - Pinteric, Uros - Jüptner, Petr (2019): Path Dependence and Local (Self-)Government Systems: A Comparison of Three CEE Countries. Politics in Central Europe. 15 (2): 193-218.

Kovářová, Iva (2018): K urnám vyrazí ve Kbelnici až v lednu. V říjnových volbách chybí kandidáti. Jicinsky.denik.cz (16 August), available at https://jicinsky.denik.cz/zpravy_region/k-urnam-vyrazi-ve-kbelnici-az-v-lednu-v-rijnovych-volbach-chybi-kandidati-20180816.html (8 May 2019).

Krishna, Anirudh (2002): Enhancing Political Participation in Democracies: What is the Role of Social Capital? Comparative Political Studies 35 (4), 437-460. 
Laudin, Radek (2018): Starostové jsou otrávení z kritiků, ti ale nekandidují. Vsi přebere správce.jihlava.idnes.cz (October 5), available at https://jihlava.idnes.cz/volby-starosta-kritika-ministerstvo-vnitra-spravce-vysocina-stritez-zdirec-1x4-/jihlava-zpravy.aspx?c=A181005_430892_jihlava-zpravy_mv (May 8, 2019).

Lebeda, Tomáš (2009): Komunální volby klamou. Krátké zastavení nad problematickými aspekty volebního systému pro obecní zastupitelstva. Acta politologica 1 (3): 332-343.

M R Martins (1995): Size of municipalities, efficiency, and citizen participation: a cross-European perspective, Environment and Planning C: Government and Policy, Pion Ltd, London, vol. 13(4), pages 441-458.

Mašová, Lenka (2018): Ve Stř́teži volby nebudou, do politiky nikdo nechce. Týdeník Vysočina, (27 September).

Meissnerová, Šárka (2018): Ve Skomelně není koho volit, kandidáti jsou tři. rokycansky.denik.cz (August 22), available at https://rokycansky.denik.cz/zpravy_region/ve-skomelne-neni-koho-volit-kandidati-jsou-tri-20180822.html (8 May 2019).

Ministry of the Interior of the Czech Republic (2018): “Dodatečné volby do zastupitelstev obcí dne 26. ledna 2019" (28 October), https://www.mvcr.cz/clanek/dodatecne-volby-do-zastupitelstev-obci-dne-26-ledna-2019.aspx (8 May 2019).

MPČR (Místní průvodce po České republice (2019)): "Information about municipalities." Místní průvodce po České republice, available at https://www.mistopisy.cz/ (July 28, 2019).

Monitor (2019): "Financial situation in municipalities." Monitor, available at https://monitor. statnipokladna.cz/2018/ (8 May 2019).

Monitor (2019): "Universal calculator." Monitor, available at https://monitor.statnipokladna. cz/2018/obce/detail/00291773\#rozpoctova-odpovednost-kalkulacka (8 May 2019).

Newton Kenneth (1982): Is Small Really so Beautiful? Is Big Really so Ugly? Size, Effectiveness and Democracy in Local Government, Political Studies 30 (2): 190-206.

Nič Husárová, Kateřina (2019): V Děkově konečně znají nové zastupitele. Rakovnický deník, (28 January).

Obec Lipovec. Oficiální stránky, available at https://lipovec.cz/organizace-a-instituce/ (8 May 2019).

Obec Roblín. Řádná účetní uzávěrka sestavovaná k rozvahovému dni 31. 12. 2018, available at https://roblin.cz/assets/File.ashx?id_org=14019 \& id_dokumenty=1567 (8 May, 2019).

Obec Víska u Jevíčka. Závěrečný účet za rok 2010, available at http://viskaujevicka.cz/wp-content/ uploads/2019/04/zaverecny_ucet_2010-1.pdf (8 May, 2019).

Orholz, Pavel (2018): V Němčicích se volby konat nebudou. Právo: jihozápadní Čechy (16 ugust).

Osouch, Marek (2018): V obcích se našli kandidáti pro volební reperát, bezvládí skončí. brno.idnes. cz (November 22), available at https://brno.idnes.cz/volby-leden-2019-bezvladi-obce-dlouha-lhota-lipovec-hodejice-blanensko-vyskovsko-197-/brno-zpravy.aspx?c=A181122_440879_ brno-zpravy_mos1 (8 May, 2019).

Pospišilová, Alena - Vildová, Mirka (2018): Vypršel termín pro předložení kandidátních listin pro dodatečné komunální volby. Česká televize: Události v regionech - Praha (November 
21), available at https://www.ceskatelevize.cz/ivysilani/10118379000-udalosti-v-regionech-praha/218411000141121-udalosti-v-regionech (8 May, 2019).

Starosta? Nikdo se nehlásí. Blanenský deník (2018).

Swianiewicz, Pawel (2002): Size of Local Government, Local Democracy and Efficiency in Delivery of Local Services - International context and Theoretical Framework in Swianiewicz Pawel (eds.), Consolidation or Fragmentation? The Size of Local Governments in Central and Eastern Europe, 1-29, Budapest: Local Government and Public Service Reform Initiative - Open Society Institute.

Ryšavý, Dan (2006): Komunální je komunální a velká je velká! K hypotéze politizace lokálních politických elit. Czech Sociological Review 42 (5): 953-970.

Ryšavý, Dan (2007): První generace lokálních a regionálních politických lídrů. Social studies 4 (1-2):115-130.

Ryšavý, Dan - Šaradín, Pavel (2012): Zastupitelé českých měst a obcí v evropské perspectivě. Praha: SLON.

Saadouni, Štěpánka (2018): Ždírec nedal dohromady kandidátku do komunálních voleb, hrozí mu nucená správa. denik.cz (2 August), available at https://www.denik.cz/regiony/zdirec-nedal-dohromady-kandidatku-do-komunalnich-voleb-hrozi-mu-nucena-sprava-20180802. html (8 May, 2019).

Svoboda, Josef (2018): V některých obcích nebudou mít koho volit. Televize Nova: Ranní televizní noviny 8:00 (13 August).

Šedo, Jakub (2009): Preferenční hlasy v komunálních volbách - zdroj obměny či stability volených reprezentantů?. Acta Politologica 1 (3): 344-365.

Ševela, Vladimír (2018): Sto procent! Anebo nic. Schopní lidé se často do politiky nehrnou, na stovkách míst vznikla ve volbách pouze jedna kandidátka, nebo o posty neměl zájem nikdo. Ego.ihned.cz (12 October). https://ego.ihned.cz/c1-66285150-sto-procent-anebo-nic-schopni-lide-se-casto-do-politiky-nehrnou-na-stovkach-mist-vznikla-ve-volbach-pouze-jedna-kandidatka-nebo-o-posty-nemel-zajem (8 May, 2019).

Teorell, Jan (2003): Linking Social Capital to Political Participation: Voluntary Associations and Network of Recruitment in Sweden. Scandinavian Political Studies 26 (1): 49-66.

Teorell, Jan (2006): Political Participation and Three Theories of Democracy: A Research Inventory and Agenda. European Journal of Political Research 45 (5): 787-810.

Tolarová, Jana. Myslivecké sdružení Diana Horšice, available at http://www.obec-horsice.cz/o-obci/spolky/myslivecke-sdruzeni-diana-horsice-2 (8 May 2019).

V pěti obcích se volit nebude, místní nechtěli kandidovat. Právo: Praha - střední Čechy (23 August 2018).

V pěti obcích se letos nevolí. Není totiž koho. Právo: jižní Morava - Vysočina (5 October 2018).

Verba, Sidney - Scholzma Kay Lehman - Brady Henry E. (1995): Voice and Equality: Civic Voluntarism in American Politics. Cambridge: Harvard University Press.

Ve Vísce opět nebudou řádné obecní volby. Mladá fronta Dnes: pardubický kraj (11 August 2018).

Votruba, Viktor (2018): Tady si voliči nevyberou. 5plus2: Mělnicko, (5 October). 
Volby.cz. (2019): Local elections 1994-2019. Czech Statistical Office. Available at https://volby. cz/ (8 May 2019).

Vráblíková, Kateřina (2008): Politická participace - koncepty a teorie. Czech Journal of Political Science (4): 366-387.

Vráblíková, Kateřina (2009): Politická participace a její determinanty v postkomunistických zemích. Czech Sociological Review (5): 867-897.

Žítková, Barbora (2018): Obecní a senátní volby 2018. Česká televize: Události (5 October), available at https://www.ceskatelevize.cz/porady/1097181328-udalosti/218411000101005/.

Petr Dvořák graduated in Political Science from the Faculty of Social Studies, Masaryk University, Czech Republic. He is currently studying for a doctoral degree program there. His area of interest includes Czech politics and political representation. Contact: 413425@mail.muni.cz.Orcid ID: 0000-0002-3107-6070

Stanislav Balík is a professor of Political Science at the Faculty of Social Studies, Masaryk University, Czech Republic. He specializes in local politics and modern Czech politics. Contact:12180@mail.muni.cz. ResearcherID: C-3862-2018. 